\title{
Provision of Educational Programs for Student-Teachers in Tanzania: Relevant Lessons from Crash and Normal Trained Teachers
}

\author{
Benjamin Mbeba Meli \\ Dares Salaam University College of Education, Faculty of Humanities and Social sciences, Department of \\ History, political Science and Development Studies, P.O. Box 2329 Dares Salaam Tanzania, East Africa \\ Email: benjaminmbeba@gmail.com
}

\begin{abstract}
This paper is based on a study that tried to establish the comparison of established two educational programs for student-teachers in Tanzania. The findings revealed that for the normally trained teachers, their academic programs and content were better designed compared to licensed trained teachers and thus they were more effective in teaching than the licensed trained teachers. It was recommended first and foremost, that The Ministry of Education, Science and Technology (MoEST) should provide and support general and specific in-service training programs, especially for the crash trained teachers, so that they become more knowledgeable and skilled in the teaching and learning processes. Furthermore, the MoEST should support the existing teachers' resource centres with regular and continuous in-service activities at the centres to equip teachers' knowledge and skills.
\end{abstract}

Keywords: teachers' knowledge and skills, Tanzania, students and teachers

DOI: $10.7176 / \mathrm{JEP} / 11-9-27$

Publication date:March $31^{\text {st }} 2020$

\subsection{Introduction}

In 2002, the government through the Ministry of Education, Science and Technology (MoEST) introduced two major educational programs for the aim of solving the acute shortage of teachers in both primary and secondary schools. These programs were Primary Educational Development Program (PEDP) and Secondary Educational Development Programs (SEDP). Concurrent with PEDP implementation in 2002, a three month college-based teacher training program was introduced. Teachers were introduced to teaching and other related courses without initial and prerequisite knowledge necessary for one to pursue teacher training. Other learning time was spent in the schools. The Government uphold that the crash program was beneficial, as within two years of implementation of the program the demand for teachers had been almost met (URT, 2004). The idea of SEDP was that within three months trained teachers will be adequately equipped to teach students in secondary schools. Nevertheless, through the crash program, unfortunately, the academic aspect of teacher education was not emphasized but the emphasis was on pedagogy. In 2006, the MoEVT employed 3,500 crash trained teachers in secondary schools and in the same year 2006, about 6,000 high school leavers joined the same short course at various Teachers Training Colleges in the country, and later the they were to teach in secondary schools as licensed trained teachers under the directive that within five years of licensed teaching, they should upgrade their levels of education and acquire a Diploma or a Degree otherwise they would be terminated from employment (Nyangwe, 2007; Mussika, 2002; Mosha, 2004; Fungo, 2008).

Tanzania Institute of Education (TIE), on other hand, developed a new teacher training curriculum as one of its efforts to improve the quality of education. The aim of the curriculum was to improve the quality of teachers prepared in teachers training colleges (Katunzi, 2000). The teacher training curriculum brought changes in curricula at both at primary and secondary school levels (Katunzi, 2000). The emerged new curricula placed great emphasis on reforming a two years teacher training program. That was mainly meant to prepare competent teachers who will be teaching in primary and secondary schools as well as in teachers' training colleges (ibid). The curriculum was expected to provide competence to student teachers in the following aspects: knowledge skills, methodology, pedagogic skills and other teacher basic competence aspects such as marking assignments correctly, language mastery, subject mastery and problem-solving. This paper therefore, deplores the into the differences in content and time allocation between the crash and normal training programs in Tanzania and their effects on student-teachers' academic qualifications.

\subsection{Philosophical Stance for Reforms in Teacher Education and Training}

In the early 1980's, debates on an increased role of schools in training teachers were featuring in teacher education and training circles (Furlong et al., 1988). It is recorded that although in countries such as England and Wales, the acceptance of the school-based teacher education was in early1990's the idea was not entirely new. Furlong et al., (1988: pg ) trace the origin back to 1944 when it was first suggested that:

"the key to effective training (of teachers) was to give the practical side greater weight (in which) 
staff of schools in which the students were placed on teaching practice should be primarily responsible for directing and supervising them".

The idea that teacher education and training is a process of specialized professional preparation is what triggered the shift from college-based to more school-based teacher education initiatives. In England, the trend in change of institutions responsible for preparing teachers was a result of demand for a different focus on teacher training, from teacher training colleges to colleges of education to institutes of (higher) education; each of which carried a different philosophical meaning and focus (Bell. 1981). The teacher training colleges, focused on producing the 'good teacher', one with moral responsibility (Ibid). As such, the role of teacher training was to provide some 'charismatic education', some teacher qualities that would enable the teacher to perform. In Tanzania, Colleges of Education that followed the Teacher Training Colleges in 1960s, sought to produce educated teachers. Emphasis was on education not training. Therefore, teacher training became part of the higher education system and within universities where they were to be equipped with analytic, intellectual skills to enable them to improve and evaluate their classroom performance (Bell, 1981). The emergence of the Teacher Education Institution (TEI)-school partnership therefore could be associated with the public demand for a better system for teacher preparation. By the beginning of 1980's the UK Department for Education and Science (DES) issued a series of statements on teacher training. One of those was that initial teacher training of all qualified teachers should include studies closely linked with practical experience in schools and involve the active participation of experienced practicing school teachers.

Furlong et al, (1988) did a research at various educational institutions in England and found that learning to teach was at four levels: first, was direct practice where training was through experience in schools and classrooms; secondly, indirect practice that is detached training in practical matters conducted in classes or workshops within the training institutions; third, practical principles in which critical study of principles of practice and their use were made and fourthly, disciplinary theory in which critical study of practice and its principles in the light of fundamental theory and research were also in place. The four levels revealed that the move was towards the training of reflective practitioners rather than of those seeking to apply theory. While in the notion of practices as the application of theory created a psychological gap between theory and practice which no amount of practice could bridge, the gap was not experienced in this project because theoretical aspects at levels $\mathbf{b}$, $\mathbf{c}$, and $\mathbf{d}$ were given professional relevance at level a. School-based trained teachers were generally rated by school heads as better than those from other routes.

In 1989 the Licensed Teachers Scheme was piloted in England and Wales whose essence was that it was individually tailored and employment-based, not course-based (Arora, 2005). It was an apprenticeship initiative placing students entirely in the hands of schools alone. However, it was established that more than half of the licensed teachers were qualified as teachers overseas and many of the others has had some teaching experience (Arora, 2005).

While the Licensed Teachers Scheme was entirely school-based, a similar scheme, the Articled Teachers Scheme, was run in partnership between training institutions and local education authorities which was first implemented as a pilot in 1990 (Arora, 2005). Student teachers would enrol in a two-year of Post Graduate Certificate of Education (PGCE) program at a training institution but they would be trained as far as possible in school and would be paid (Aurora, 2005:109). It is important to note that these reforms were not always well accepted. Teacher unions were reported to have been cautious-seeing the moves as a loophole for authorities to employ the cheaper earn-as-youlearn than the trained teachers, a quick-fit strategy and a fast low cost solution to teacher shortages as well as a dilution of standards in a rush to get more teachers (Arora,2005).

In America, teacher training followed a similar trend from teacher training in normal schools, to teacher training colleges to university faculties and then to professional development schools and licensed programs (Lewin, 2002). It has been noted that the use of university faculties for teacher training brought about competition for resources that led to education faculties usually emerging the losers. But that was not all, the gap between teacher training and the school widened as the experts were increasingly being prepared in isolation, to the dissatisfaction of the public, the employers, parents and students. Also, it has been noted that due to problems within the faculties of education, teacher production could not suffice the demand for teachers in terms of numbers and quality. The emergence of the professional development schools and alternative licensure programs were a reaction to the teacher quality and supply issues (Smith, 2009).

As noted earlier, there are competing discourses on teacher training and development ranging from universitybased theory-into-practice to craft apprenticeship based in schools. Adoption of university-school partnership is 
increasingly becoming a more compelling venture as theory and practice are integrated in the form of collaboration. However, this understanding is in principle a middle position of the extremes-the Theory into Practice and the Craft Apprenticeship models.

In most countries preparation of teachers or teachers' education is conducted by teacher education institutions managed by Ministries of Education or based on the Universities. The terms used for teachers' training institutions are: Teacher Training Colleges (TTCs), Colleges of Education (CE) or Teacher Training Institutions (TTIs). The terms are used synonymously, depending on the historical influence of the country (Osaki, 2003). However, the primary task of an education institution is the preparation of individuals so that they gain teaching expertise. Berliner (1988) stresses that, over the years, teacher preparation institutions continued to struggle with the question of how to provide the kind of experiences that are conducive to the preparation of students to become successful teachers.

\subsection{Teacher Preparation in Educational Foundations}

Teacher preparation is a systematic process, which focuses on preparation of teachers, giving them guidance and support towards the acquisition of various relevant educational theories for skilful competence as well as effective performance in teaching and learning at classroom level. It involves teachers studying courses such as educational psychology, philosophy of education and sociology of education (Adea, 2003). The three subjects can be considered to constitute educational foundations focusing on teachers' development of skills, classroom management, teaching methods, educational evaluation and educational guidance as well as counselling with administration (Bengtson, 1993).

Most governments have set standards that vary with the kind of schooling for which the training is designed. However, in some countries, people with low academic qualifications enter teacher training (Lewin, 2004). Nyerere (1999) points out that, teachers undergo a special teaching course at colleges, because born teachers are rare and so they need to be exposed more frequently to the latest ideas and techniques in the subject matter in their field through seminars, workshops and conferences.

\subsection{The Study Area}

The study on which this paper is based was conducted in Morogoro, Iringa, Songea and Bunda municipalities. Reasons for selecting these areas were: first, they had teacher training colleges which offered both crash and normal teacher training programs. Therefore, it was likely that some of the licensed trained teachers were posted to schools within those particular areas. Second, it might have been convenient for the researcher because schools and colleges were close to each other, so it was easy for the researcher to move from where knowledge was given to where practice was done.

\subsection{Methodology}

Primary data were collected using both qualitative and quantitative methods, where secondary data obtained from literature search and review of relevant official documents. The literature review further highlighted the philosophical stance for reforms in teacher education and training and teacher preparation in education foundation. Two phases of data collection and analysis were conducted. In the first phase, qualitative data was based on the contents of the two established programs (crash and normal), academic qualifications of student-teachers and facilitators of these two programs. The second phase of data collection focused on quantifying some variables on pertinent issues discussed during the in-depth interviews, observation and focus group discussions.

\subsection{Findings of the Study}

The findings of the study are presented under the following subsection: demographic profile and socio-economic characteristics of the respondents, contents and time allocated for training period between crash and normal programs and academic qualifications of the student-teachers.

\subsection{Demographic and Socio-economic Characteristics of the Respondents}

It was important to find out that the demographic and socio-economic characteristics that were involved in the study by looking on main variables such as age, sex and levels of education. These variables would provide indication if at all there was equality or differences of the two contents offered to both crash and normal programs, student-teachers and facilitators' (tutors') academic qualifications. The distribution of the respondents in terms of sex, age and level of education is presented in Table 1 . 
Table 1: Demographic and socio-economic Characteristics of the Respondents

\begin{tabular}{|c|c|c|c|c|c|c|c|c|c|c|c|}
\hline \multirow{2}{*}{$\begin{array}{l}\text { Respondents' } \\
\text { Name }\end{array}$} & \multicolumn{2}{|l|}{ Sex } & \multicolumn{4}{|c|}{ Age } & \multicolumn{5}{|c|}{ Level of Education } \\
\hline & $\frac{0}{\frac{0}{5}}$ & 总 & $\begin{array}{l}\stackrel{n}{\mathfrak{1}} \\
\stackrel{1}{n}\end{array}$ & గి & 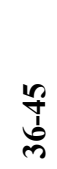 & $\begin{array}{l}n \\
0 \\
b \\
b\end{array}$ & 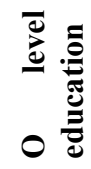 & 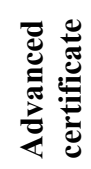 & 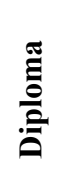 & 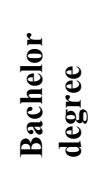 & $\frac{0}{\frac{\omega}{5}}$ \\
\hline Headmasters & 12 & - & - & - & 8 & 4 & - & - & 9 & 3 & - \\
\hline Headmistress & - & - & - & - & - & - & - & - & - & - & - \\
\hline $\begin{array}{l}\text { Normal } \\
\text { trained } \\
\text { teachers }\end{array}$ & 16 & 14 & - & 5 & 22 & 3 & - & - & 23 & 7 & - \\
\hline $\begin{array}{l}\text { Licensed } \\
\text { trained } \\
\text { teachers }\end{array}$ & 24 & 6 & - & 28 & - & - & - & 30 & - & - & - \\
\hline Students & 30 & 30 & 60 & & & & 60 & - & - & - & - \\
\hline $\begin{array}{l}\text { Students' } \\
\text { parents }\end{array}$ & 16 & 8 & - & - & 8 & 6 & - & 5 & 12 & 7 & - \\
\hline Tutors & 20 & 12 & - & - & 3 & 29 & - & - & - & 23 & 9 \\
\hline $\begin{array}{l}\text { Municipal } \\
\text { officials }\end{array}$ & 2 & 2 & - & 2 & 2 & & - & - & - & 2 & 2 \\
\hline $\begin{array}{l}\text { MoEVT } \\
\text { officials }\end{array}$ & 1 & 1 & - & 1 & 1 & & - & - & - & 1 & 1 \\
\hline TIE officials & 1 & 1 & - & - & 1 & 1 & - & - & - & 1 & 1 \\
\hline $\begin{array}{l}\text { Zonal } \\
\text { secondary } \\
\text { school } \\
\text { inspectorate } \\
\text { officers }\end{array}$ & 2 & 2 & - & - & 2 & 2 & - & - & - & 1 & 3 \\
\hline Total & 124 & 76 & 60 & 36 & 47 & 45 & 60 & 35 & 44 & 45 & 16 \\
\hline
\end{tabular}

Source: Computed from field data (2014)

Data displayed in Table 1shows that out 200 respondents, $124(67 \%)$ were male while $76(33 \%)$ among the respondents were female. On the other hand, among the respondents, 36 (18\%) were in the 26-35 age group. 47 $(23.5 \%)$ were in the $36-45$ age group and $45(22.5 \%)$ were in the $46-55$ age group. The table revealed that male were more than female and it was found that, most of the respondents who provided their opinions about the contents of the two established programs (crash and normal), academic qualifications of both student-teachers and facilitators of the programs were at age of 26-55 years. This indicated that they were too matured enough in terms of working experience to give the opinions on matters pertaining educational programs in Tanzania.

Furthermore, Table 1 shows that since it is believed that education is the engine of the socio-economic and political development of any society, respondents were asked to state their level of education. Table 1 shows that out of 200 respondents interviewed on their level of education, 60 (30\%) were Form IV level, $35(17 \%)$ were Form VI leavers, $44(22 \%)$ Diploma education holders. Also 45 (22.5\%) were Bachelor degree holders and only $16(8 \%)$ were Masters degree holders. This revealed that their opinions were relevant to what was going on to the quality of education in Tanzania.

\subsection{Contents and Time Allocation between Crash and Normal Teacher Training Programs}

The study revealed that the contents and time allocation between crash and normal trained teacher programs varied. Findings from all the respondents revealed that the content for normal program was designed for two years for Diploma course. 2 TIE officials, 2 MoEVT officials and 32 tutors pointed out that normal trained teachers program was designed for two years of diploma course and were required to stay at the Colleges all the time doing continuous assessments, Block Teaching Practices (BTP) and finally, they were supposed to sit for the national examination prepared by the National Examinations Council of Tanzania (Table 2). 
Table 2: Content of Two Years Diploma Course Designed for Normal Trained Teachers in Tanzania.

\begin{tabular}{|c|c|c|}
\hline Courses Taught & $\begin{array}{l}\text { Time Frame in Years } \\
1 \& 2\end{array}$ & $\begin{array}{l}\text { Hours Needed Per } \\
\text { Two Years }\end{array}$ \\
\hline \multicolumn{3}{|l|}{ Professional Courses: } \\
\hline Educational Psychology, Guidance and Counselling & $1 \& 2$ & 80 \\
\hline Foundation of Education & $1 \& 2$ & 80 \\
\hline Education Research, Measurement and Evaluation & $1 \& 2$ & 80 \\
\hline Curriculum and Teaching & $1 \& 2$ & 80 \\
\hline \multicolumn{3}{|l|}{ Academic Courses: } \\
\hline Information Communication Technology (ICT) & $1 \& 2$ & 40 \\
\hline Communication Skills & $1 \& 2$ & 40 \\
\hline General Studies & $1 \& 2$ & 40 \\
\hline Block Teaching Practice & $1 \& 2$ & 16 Weeks \\
\hline Option I Academic (Science Subjects) & $1 \& 2$ & 80 \\
\hline Option II Academic & $1 \& 2$ & 80 \\
\hline Total & $1 \& 2$ & 640 \\
\hline
\end{tabular}

Source: Computed from field data (2014).

However, the findings from respondents indicated that the content of the crash program for licensed trained teachers which was intended for training teachers for three months and was divided into four modules to meet the demands of the course and also to enable facilitators to finish the content in time. A MoEVT respondent who coordinated the crash program had the following comment:

"We divided the topics into four modules in order to enable our facilitators to teach the studentteachers well and the program was very successful."

Those four modules were categorised as follows: Teaching and Learning, The Teacher and Teaching Profession, Adolescence and Schooling, along with School Organization and Management (see Tables 3 to 6).

Table .3: Module I (Teaching and Learning).

\begin{tabular}{|l|c|}
\hline Name of Topic & Coverage in Hours per week \\
\hline Teaching and Learning & 3 \\
\hline Curriculum Materials & 2 \\
\hline The Syllabus & 4 \\
\hline Scheme of Work & 6 \\
\hline Lesson Plan & 8 \\
\hline Lesson Notes & 4 \\
\hline Teaching Aids & 8 \\
\hline Classroom Interaction Skills: (Teaching and Learning Methods) & 8 \\
\hline
\end{tabular}




\begin{tabular}{|l|c|}
\hline Organization and Management of A Class & 5 \\
\hline Motivation and Reinforcement & 5 \\
\hline Assessment: (Meaning and Importance) & 3 \\
\hline Assessment Procedures: (Test) & 2 \\
\hline Test Construction and Use & 6 \\
\hline Planning the Test & 3 \\
\hline Interpreting Test Scores and Keeping Student Records & 6 \\
\hline Alternative Assessment Procedures & $\mathbf{7 6}$ \\
\hline Total & \\
\hline
\end{tabular}

Source: Field data (2014).

Table 4: Module 2: (The Teacher and Teaching Profession).

\begin{tabular}{|l|c|}
\hline Name of Topic & Coverage in Hours per week \\
\hline The Teacher & NIL \\
\hline The Teaching Profession & 4 \\
\hline Professional Code of Conduct & $\mathbf{5}$ \\
\hline Total & 4 \\
\hline
\end{tabular}

Source: Field data (2014).

Table 5: Module 3: (Adolescence and Schooling).

\begin{tabular}{|l|c|}
\hline Name of Topic & Coverage in Hours \\
\hline Meaning and Significance of Adolescence & 3 \\
\hline Characteristics of Adolescents & 3 \\
\hline Guidance and Counselling & NIL \\
\hline Total & $\mathbf{6}$ \\
\hline
\end{tabular}

Source: Field data (2014). 
Table 6: Module 4: (School Organization and Measurement).

\begin{tabular}{|l|c|}
\hline Name of Topic & Coverage in Hours \\
\hline The Concept of Education and Training & 2 \\
\hline Philosophy of Education & NIL \\
\hline School as Socialization Agent & 3 \\
\hline Education Policies and Education Acts & 3 \\
\hline School Management & 3 \\
\hline Support Agencies for Teachers & 2 \\
\hline Children's Rights and Needs & 3 \\
\hline Total & $\mathbf{1 6}$ \\
\hline
\end{tabular}

Source: Field data (2014).

In making the comparison between those two programs offered to both normal and licensed teachers in Tanzania, the study revealed that there was a major difference in the structure of the programs designed between the two types of teachers. Table 1 show that, normal trained teachers were well prepared in their teaching profession. Six courses had eighty hours for two years of training period. This indicated that they had enough time to learn and discuss various assignments given by their tutors. Likewise, Communication Skills and General Studies had also forty hours for each course. Again, they had sixteen weeks for Block Teaching Practice which enabled them to practice what they learnt in classes. However, from Tables 3 to 6 , the program for licensed teachers looked different from the normal trained program. The program for licensed teachers is too condensed for the teachers to grasp requisite subject matter about teaching and learning. Some of the topics were not allocated any time (Philosophy of Education, The Teacher as well as Guidance and Counselling of Adolescents). This implies that tutors under crash program had discretion to allocate time to some content according at their own convenience. This trend of affairs leads to suggest the following: first, time allocation varied from one class to another and and secondly some topics were omitted completely from the program.

This being the case, teachers lacked adequate knowledge and skills on how to go about guiding and counselling students, including other members in the community. Guiding and counselling skills as a topic was not taught to licensed teachers despite that they were going to work in schools whose students were at their adolescent growth spurt. It is obvious that due to many social, economic and physical factors, adolescents encounter many problems such as distress, drug abuse, and prostitution, pick pocketing and other crimes which affect the young men and girls. All four zonal Secondary School Inspectorate Officers had the following views on the absence of Guidance and Counselling Course to the licensed teachers, that:

“.psychologically, licensed teachers were not prepared enough to meet many challenges related to their work like how $t$ deal with staff, individuals, society and community at large. Some of these teachers were reported to have social relationship with their students, some married them and others failed to control their emotions and therefore fought with students".

In addition, some of the topics available in the normal teachers' program were left out completely in the crash teacher training program. For example, topics such as Educational Research, Measurement and Evaluation in which teachers learn different techniques of assessing their learners, going about research and applying them in their daily school activities in the future were not part of the program. The absence of those topics affected the licensed trained teachers to teach effectively. However, all the 16 respondents from TIE, MoEVT and Headmasters/mistress when asked by the researcher to give their general views about the two programs in terms of improving secondary education in Tanzania, they had the following comments:

"the government had good vision for citizens. Both programs are good despite the fact that some people denounce the crash program as being ineffective. But the crash program in general was sufficient to meet the high demands of teachers due to recent mushrooming of Ward/Village community secondary schools. However it should be remembered that; the objective of the program was to curb the acute shortage of teachers. In that respect, those teachers have done a commendable job than what was expected of them". 
From the above findings, it could be concluded that normal teacher training program had more opportunity to prepare good teachers compared to crash teacher training program which content was not enough to enable teachers to acquire all teaching and learning skills. Dove (1986) points out that teacher preparation is always a systematic process which focuses on preparation of teachers, giving them guidance and support towards the acquisition of various relevant educational theories for skilful competence as well as effective performance in teaching and learning at classroom level. It involves teachers studying courses such as educational psychology, philosophy of education and sociology of education. These courses should take a long training period in order to enable teachers to be competent. Conant (1963) pointed out that, whether preparation for teaching extends over a few weeks or many years, the distinctive part of education is and has been common for pedagogy, the study of the art of teaching. Thus, the shorter the education preparation for any profession is, the heavier the emphasis on methods, and the greater the isolation from other disciplines. The result is a student with a limited mind and narrow understanding.

\subsection{Student-Teachers' Academic qualifications}

One important observation noted in this study was that both student-teachers (crash and normal) programs had the same academic level qualifications. Both programs recruited student-teachers who had completed advanced secondary education (Form Six) with minimum academic qualifications of two principals and one subsidiary pass. One respondent among the tutors had the following comments on level of education between these two types of teachers that:

...academically the normal and licensed teachers are equal because they have entered into the teaching program with the same education qualifications...

In addition, 28 out $32(87.5 \%)$ tutors who coordinated the crash program supported the above comment by saying that:
"a good teacher does not necessarily have to be one who stays in the classroom for a long period of training, rather it depends on many factors like; individual education background, commitment, motivation, working environment and political support"

From the above findings, it is shown that both of the two types of teachers had the same academic qualifications for joining the teaching programs but, the ability of to teach depended much on the teaching and learning environment during their training program (Osaki, 2003). This is carried further by Osaki (2003) who argues that teacher training program in Tanzania for both licensed and normal trained teachers is ineffective in preparing competent teachers because the whole process has been influenced by politics rather than remaining in the realm of academicians. The politicians have been intervening in the education sector by forcing the community to construct a lot of secondary schools without system of preparing enough teachers in order to win the election campaigns. The findings revealed that the crash teacher training program was delivered by qualified and experienced facilitators in the four teacher training colleges: Bunda, Morogoro, Kleruu and Songea (MoEVT, 2004). 2 TIE officials, 2 MoEVT officials and 32 tutors went further to point out that the tutors who ran the crash teacher trained program had the requisite qualifications for running the teaching program. 23 out $32 \quad(72 \%)$ had bachelor degree in education and 9 out $32(28 \%)$ had masters degree in education and beside they had long experience of teaching.

Therefore, from the above findings, it is clear that the crash teacher training program involved qualified and long experienced facilitators who had good teaching pedagogical skills. This was contrary speculations that they were ill trained. URT (2000) gives the guidelines of the minimum qualifications of the tutors who teach in Teachers' Training Colleges; that they should have atleast first degree, a level which the trainers (tutors) are well trained enough in teaching profession to be effective in imparting knowledge and other pedagogical skills to the learners that is the would be teachers (Mussika, 2002).

\subsection{Conclusions}

Looking at the findings and discussion above, a number of conclusions can be made. A major observation is that crash teacher trained program had more challenges than normal training program. This was because the program itself was delivered in a short period of time such that it was not possible to equip student-teachers with requisite pedagogical skills to be effective and comptent teachers. This is contrary to what Shaw (1992) belives in thus:

"...... the process of becoming a professional teacher, however, is a lifelong process, which involves years of acquiring knowledge on the teaching, learning process, trying out new teaching style that engage learners, observing others, effective classroom management, good preparation, effective use of teaching/learning materials, receiving and giving feedback....."

It is vivid from the above excerpt that, to be a teacher is a long process which makes one to spend some years of training and not a short period of time. 


\subsection{Recommendations}

Based on the study findings and the ensuing conclusion, the following recommendations are made: first and foremost, that The MoEVT should provide and support general and specific in-service training programs, especially for the crash trained teachers, so that they become more knowledgeable and skilled in the teaching and learning processes. Furthermore, The MoEVT should support the existing TRC so that there are regular and continuous in-service activities going on at the centres to equip the teachers with more knowledge and skills. These resource centres will help teachers to acquire knowledge and skills which were not attained during the training period and to use that knowledge in the classrooms.

\subsection{References}

Adea, B., (2003). Quality, Access, Equity: the Teaching Profession. London: Inc. Press

Arora, R., (2005). Race and Ethnicity in Education. Aldershot.: Ashgate Publishing Limited.

Bell, A., (1981). 'Structure, Knowledge and Social Relationships in Teacher Education', British Journal of Sociology of Education, Vol2, No5, pg 3-23.

Bengtson, J., (1993). 'Theory and Practice: Two Fundamental Categories in Philosophy'. A Journal for Teacher Education Review, Vol. 4. No.3.pg 33-139.

Berliner, D., (1988). The Development of Expertise in Pedagogy. Boston: Mifflin Company.

Conant, J., (1963). The Education of American Teachers. New York: McGraw-Hill Book Company.

Frasier, G.W., (1956). An Introduction to the Study of Education. New York: Harper and Row Brothers limited.

Fungo, M., (2008). Stakeholders' Views Towards One-Month Teacher Training Program for Form Six Leavers in Tanzania, Unpublished M.A (Educ) Dissertation, Faculty of Education, University of Dares Salaam.

Furlong, V. J., Hirst, P. H., Pocklington, K. and Miles, S., (1988). Initial Teacher Training and the Role of the School. Milton: Keynes Open University

Katunzi, N., (2000). The Community School in Tanzania: A Case Study of Kwamsisi Project. A Thesis submitted to the Faculty of Graduate Studies in Partial Fulfilment of the Requirements for Degree of Philosophy. Calgary: DUP

Lewin, K. M., (2002). Projecting Secondary School Expansion in Tanzania: The Art of the Possible. Briefing on Secondary School Expansion in Tanzania. Dar es Salaam: DUP

Lewin, K., (2004). Financing Secondary Education in Developing Countries Strategies for Sustainable Growth. Paris: UNESCO.

Meli, B (2014). An Evaluation of Teacher Education and Training in Tanzania, Comparative Study between Licensed and Normal Trained Teachers, Unpublished PhD thesis Submitted to University of Dare Salaam

Ministry of Education, Science and Technology (2004). Education System in Tanzania Towards the year 2000, Dares Salaam, Government Printers

Mosha, H. J., (2004). 'New Directions in Teacher Education for Quality Improvement in Africa'. Journal of the Faculty of Education. University of Dar es Salaam. Vol. -. No. 24. pp.45- 68.

Mussika, E. (2002). Teachers Training and the class room Performance of Grade IIIA Teachers in Tanzania. Unpublished M.A (Ed) Dissertation. Faculty of Education, University of Dar es Salaam.

Nyangwe, E. (2007). Specialization in Teaching at Primary School Level in Tanzania. An Investigation on the Effects of Training and Posting in Rungwe District, Unpublished M.A. (Educ) Dissertation, Faculty of Education, University of Dares Salaam.

Nyerere, J.K, (1999). The Speech Addressed at the Open University of Tanzania in Dares Salaam on $5^{\text {th }}$ March, 1999 on the Occasion of receiving a Doctorate of Letters (Honorius Causa) degree.

Osaki, K., (2003). Capacity Building of Teachers Training Institutions in Sub-Saharan Africa: Pre-service Teacher Education Program .Dakar. UNESCO

Shaw, R., (1992). Teacher Training in Secondary Schools. London: Clays Limited.

Smith, M., (2009). Impact of Professional Development School. University of Wisconsin. Platteville Design Case, Examples and Tips. Sanfransisco: Inc. Press.

Trowbridge, L., and Bybee, R., (1996). Teaching Secondary Schools: Strategies for Developing Scientific Literacy. Columbus: Merrill Publishing Company.

United Republic of Tanzania, (2000). Secondary Education Master Plan [SEMP] (2001-2005). Dar es Salaam : Ministry of Education and Vocational Training. 